\title{
Animal cysticercosis in indigenous Brazilian villages
}

\author{
Cisticercose animal em aldeias indígenas brasileiras \\ Samuel Carvalho de Aragão ${ }^{1}$; Germano Francisco Biondi ${ }^{1}$; Luis Gustavo Ferraz Lima ${ }^{2}$; Cáris Maroni Nunes ${ }^{2 *}$ \\ ${ }^{1}$ Departamento de Higiene Veterinária e Saúde Pública, Faculdade de Medicina Veterinária e Zootécnica, \\ Universidade Estadual Paulista - UNESP \\ ${ }^{2}$ Departamento de Apoio, Produção e Saúde Animal, Curso de Medicina Veterinária, Universidade Estadual Paulista - UNESP
}

Received November 23, 2009

Accepted March 11, 2010

\begin{abstract}
Sanitary inspection of beef and pork meat has been the major tool for diagnosing animal cysticercosis and for preventing taeniasis in Brazil. The indigenous villages Jaguapiru and Bororo are located close to the urban area of the municipality of Dourados in the State of Mato Grosso do Sul, Brazil, where precarious basic sanitation conditions are observed. Both cattle and pigs are raised for self-consumption of meat and milk as well as for sale on the external market, generally without official sanitary inspection. In this study, 96 bovine carcasses and 117 pig blood serum samples from animals raised in these indigenous villages were evaluated for the presence of metacestodes by postmortem evaluation, and anti-Taenia sp. antibodies were investigated using the indirect ELISA test. Metacestode forms were observed in $18.7 \%$ of the bovine carcasses, and $9.4 \%$ of the pig serum samples were positive for anti-Taenia sp. antibodies. The occurrence of animal cysticercosis in the villages may favor the occurrence of this zoonosis in the indigenous populations. Enforcement of proper slaughter and sanitary inspection conditions are urgently needed for controlling the taeniasis-cysticercosis complex among the indigenous population.
\end{abstract}

Keywords: Taenia saginata, Taenia solium, cysticercosis, indigenous population.

\section{Resumo}

A inspeção sanitária da carne bovina e suína tem sido a principal forma diagnóstica da cisticercose animal e da prevençấo da teníase no Brasil. As aldeias indígenas Jaguapirú e Bororó estáo localizadas próximo à área urbana do município de Dourados-MS, com condiçóes precárias de saneamento básico, onde bovinos e suínos são criados como fonte de alimento para consumo próprio, bem como para comercialização externa, geralmente sem inspeção sanitária oficial. Neste estudo, 96 carcaças bovinas e 117 amostras de soro de suínos, criados nas aldeias indígenas, foram avaliadas para a presença de formas metacestóides à inspeção sanitária e de anticorpos anti-Taenia sp. ao teste ELISA, respectivamente. Observaram-se 18,75\% de positividade para cisticercose bovina e 9,4\% para cisticercose suína. A ocorrência do complexo teníase-cisticercose nas aldeias pode favorecer a ocorrência desta zoonose na população indígena. Condiçôes adequadas de abate e inspeção sanitária dos animais destas aldeias se fazem urgente para o controle do complexo teníase-cisticercose na populaçấo indígena.

Palavras-chave: Taenia saginata, Taenia solium, cisticercose, população indígena.

The taeniasis-cysticercosis complex is a cosmopolitan zoonosis that is highlyprevalent in the agricultural zones of Latin America, Asia and Africa (ALMEIDA et al., 2002). A human being acquires taeniasis by consuming raw or poorly cooked beef or pig meat or viscera containing larvae forms (metacestodes) of Taenia saginata, Taenia solium or Taenia asiatica, respectively. Humans can also act as an intermediate host when they ingest viable eggs from the environment and develop the metacestode forms of T. solium, particularly in the central nervous system (PAWLOWSKI; ALLAN;

\footnotetext{
*Corresponding author: Cáris Maroni Nunes

Departamento de Apoio, Produção e Saúde Animal,

Curso de Medicina Veterinária, Universidade Estadual Paulista - UNESP,

Campus Araçatuba, Rua Clóvis Pestana, 793, Jardim D. Amélia,

CEP 16050-680, Araçatuba - SP, Brasil

e-mail: caris@fmva.unesp.br
}

SARTI, 2005). Animal cysticercosis results in economic losses because of condemnation of carcasses or treatment leading to reduction of the meat value, in addition to the weight loss seen among infected animals (BARBOSA et al., 2003).

Occurrence of animal cysticercosis has been evaluated using different detection methods in some Brazilian regions (PRATA, 1982; SCHENK, M.A.M; SCHENK, J.A.P., 1982; BARRA; FERREIRA, 1983; UNGAR; GERMANO, 1992; REIS et al., 1996; CARMO et al., 1997; SAKAI et al., 2001; FUKUDA et al, 2003; GOTTSCHALK et al., 2006; SILVA et al., 2007) but not in indigenous villages.

We undertook an evaluation of the occurrence of cysticercosis in the cattle and pig populations in two indigenous Brazilian villages located at the "Francisco Horta Barbosa" indigenous reserve, which is $5 \mathrm{~km}$ away from the urban center of the municipality of

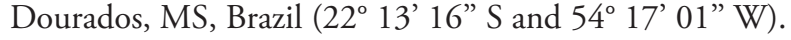


This area consists of 3,500 ha divided into two distinct regions: the villages of Jaguapiru and Bororo, with 4,404 and 4,608 inhabitants respectively. The reserve had 1,926 homes in 2003 and only $35 \%$ of these had an indoor plumbing water net and only $8 \%$ of those had toilets with sewage disposal facilities (FUNASA, 2003). Cattle and pigs are raised mainly for the communities' own consumption of meat and milk and, to a lesser extent, to put on the external market. A previous survey conducted by the Department of Agricultural Inspection and Protection of the State of Mato Grosso do Sul (IAGRO, technical information) established that there were 738 heads of cattle in these villages, with additional presence of pigs, which were usually reared around the homes without restriction. These factors may favor transmission of the taeniasis-cysticercosis complex inside the villages as well as in the metropolitan region of Dourados, MS, due to trading of beef and pig meat.

This study was approved by the Ethics Committee of the School of Veterinary Medicine and Animal Science at UNESP, Botucatu campus, and by the Department of Agricultural Inspection and Protection of the State of Mato Grosso do Sul, Brazil.

The presence of bovine cysticercosis was evaluated by postmortem inspection of 96 crossbreed animals of both sexes and between 2 and 9 years of age. Nine of them were slaughtered at the village and inspected in the field; 17 were slaughtered at a private slaughterhouse in Bataipora and 70 animals were slaughtered at another private slaughterhouse in Pedra Bonita. The minimal sample size was defined assuming normal distribution, prevalence of $5,95 \%$ confidence level and absolute precision of 5\%. Routine sanitary inspection of the carcasses for metacestode forms of Taenia saginata was performed on cuts from the masseter muscle, tongue, diaphragm and heart, and these inspections followed the Brazilian Ministry of Agriculture norms (BRASIL, 2007).

The presence of anti-Taenia sp. antibodies was tested to evaluate swine cysticercosis in the entire pig population present at that time, since postmortem evaluation was not possible because of logistical problems. Indirect ELISA testing was performed in accordance with Nunes et al. (2000) with the use of vesicular fluid from T. saginata metacestodes as the antigen. Blood samples were taken from the jugular vein of 117 crossbred pigs of up to 9 months of age, originating from 13 owners. Serum samples were conserved at $-20^{\circ} \mathrm{C}$ until processing.

The presence of metacestode forms of T. saginata was observed in $18.8 \%(18 / 96)$ of cattle tested during sanitary inspection. Of these, $6.2 \%$ (6/96) had live metacestodes and $12.5 \%$ had calcified forms. This prevalence was higher than in most previous reports from other authors on cattle from the State of Mato Grosso do Sul. Schenk, M.A.M. and Schenk, J.A.P. (1982) observed positivity of 1.0\%, Barra and Ferreira (1983) reported that 3.9\% of the slaughtered cattle presented cysticercosis and Carmo et al. (1997) observed positive findings in $1.4 \%$. In addition to these authors, who analyzed data from the same State as the indigenous villages we studied, Ungar and Germano (1992) found positive rate of $3.9 \%$ in Presidente Prudente, SP, which is a city near to the border of Mato Grosso do Sul; Reis et al. (1996) analyzed data from slaughterhouses in the State of Minas Gerais over a 15-year period and observed a maximum positive rate of $4.0 \%$; Almeida et al. (2002) found a positive rate of $7.0 \%$ in slaughtered cattle in Uberlândia, State of Minas Gerais; Fukuda et al.(2003) observed a positive rate of $4.3 \%$ for cysticercosis in slaughtered cattle in the State of São Paulo; and Falavigna-Guilherme et al. (2006) observed
9.3\% of positivity in cattle slaughtered in Sabáudia, Paraná State. It is noteworthy that most of the abovementioned studies were conducted using sanitary inspection data from slaughterhouses dealing with animals raised for commercial purposes. This made comparison very difficult, since our results were from cattle raised mainly for the communities' own consumption. These cattle were raised in a poor sanitary environment that certainly influenced the higher prevalence. Moreover, the age of the cattle (mean of 7 years) also influenced the results in the present study, given that longer lifetimes increase the risk of acquiring infection. The age of the cattle may also have had an influence on the higher percentage of calcified cysticercosis observed (12.5\%), compared to Almeida et al. (2002) who observed a $4.3 \%$ prevalence of calcified cysticercosis in a study carried out at slaughterhouses under Federal Sanitary Inspection in Uberlândia, State of Minas Gerais.

One hundred and seventeen swine serum samples were analyzed for the presence of anti-cysticercosis antibodies and $9.4 \%$ $(11 / 117)$ of these samples were positive by ELISA test. This rate of positivity is lower than the one observed by Sakai et al. (2001) who also evaluated the presence of anti-Taenia sp. antibodies in freely raised pigs in Jequié, BA, and observed that $23.5 \%$ were positive; and by Gottschalk et al. (2006), who observed that $20.5 \%$ of the pigs raised for the producers' own consumption in Registro, SP, were positive. This higher incidence of positive findings can be ascribed to differences in the animals' ages, since most of the samples evaluated in the present study were from pigs up to 9 months of age, i.e. younger than the animals in the quoted studies. These populations also lived in areas with poor basic sanitation, particularly regarding the disposal of human waste, conditions comparable to the ones observed in the present study, albeit not from indigenous villages.

Although sanitary inspection programs in Brazil have increased over the recent decades, the poor basic sanitary conditions of Brazilian populations in agricultural and urban fringe areas leads to backyard piggery practices, with pigs raised for meat self-consumption or for sale within the community, without any sanitary inspection. Such practices may favor persistence of the taeniasis-cysticercosis complex, particularly where basic sanitation conditions are precarious (PFUETZENREITER; ÁVILA-PIRES, 2000; SCIUTTO et al., 2000; FLISSER; RODRÍGUEZ-CANUL; WILLINGHAM III, 2006), like the conditions observed in the Jaguapiru and Bororo villages.

This evidence of cysticercosis occurrence in cattle and pigs raised in the indigenous villages, which constitute a vulnerable population, may favor the occurrence of this zoonosis within the villages. Results suggest that there is an urgent need to enforce proper slaughter conditions and sanitary inspection of cattle and pigs raised in these villages, in order to decrease the risk of the indigenous population acquiring taeniasis and cysticercosis.

\section{Acknowledgements}

To Pedra Bonita ${ }^{\oplus}$ Slaughterhouse and the staff of the Federal Sanitary Inspection Program (SIF) 3359 for their contributions towards the slaughter and sanitary inspection of the animals; to the Department of Agricultural Inspection and Prevention of the State of Mato Grosso do Sul for their contribution towards the field work; to Luciane Almeida Galindo for her contribution towards formatting the text; and to Dr. José Fernando Garcia and Dr. Robin A. Atlas for English revision. 


\section{References}

ALMEIDA, L. P. et al. Cisticercose bovina: um estudo comparativo entre os animais abatidos em frigoríficos com serviço de inspeção federal e com inspeção municipal. Higiene Alimentar, v. 16, n. 99, p. 51-55, 2002.

BARBOSA, F. C. et al. Eficácia do sulfóxido de albendazole na cisticercose bovina. A Hora Veterinária, v. 22, n. 13, p. 18-20, 2003.

BARRA, A. J.; FERREIRA, C. E. Demonstrativo de algumas doenças de bovinos transmissíveis ao homem. Higiene alimentar, v. 2, n. 4, p. 191-192, 1983.

BRASIL. Ministério da Agricultura. Regulamento da inspeçáo industrial e sanitária de produtos de origem animal. Brasília, DF, 2007. 381 p.

CARMO, R. G. et al. Prevalência da cisticercose bovina no Estado do Mato Grosso do Sul. Higiene alimentar, v. 11, n. 50, p. 45-50, 1997.

FALAVIGNA-GUILHERME, A. L. et al. Cisticercose em animais abatidos em Sabáudia, Estado do Paraná. Arquivos Brasileiros de Medicina Veterinária e Zootecnia, v. 58, n. 5, p.950-951, 2006.

FLISSER, A.; RODRÍGUEZ-CANUL, R.; WILLINGHAM III, A. L. Control of the taeniosis/cysticercosis complex: future developments. Veterinary Parasitology, v. 139, n. 4, p. 283-292, 2006.

FUKUDA, R. T. et al. Evolução da cisticercose bovina em animais abatidos no Estado de São Paulo. Higiene alimentar, v. 17, n. 108, p. 21-31, 2003.

FUNDAÇÃO NACIONAL DE SAÚDE: boletim técnico. Brasília, jul. 2003.

GOTTSCHALK, S. et al. Soroprevalência e aspectos epidemiológicos da cisticercose suína em criaçôes de "fundo de quintal" na microregião de Registro-SP. Veterinária e Zootecnia, v. 13, n. 2, p. 192-200, 2006.

NUNES, C. M. et al. Comparative evaluation of an indirect ELISA test for diagnosis of swine cysticercosis employing antigen from Taenia solium and Taenia crassiceps metacestodes. Veterinary Parasitology, v. 93, n. 2, p. $135-140,2000$.
PAWLOWSKI, Z.; ALLAN, J.; SARTI, E. Control of Taenia solium taeniasis/cysticercosis: from research towards implementation. International Journal of Parasitology, v. 35, n. 11-12, p. 1221-1232, 2005.

PFUETZENREITER, M. R.; ÁVILA-PIRES, F. D. Epidemiologia da teníase/cisticercose por Taenia solium e Taenia saginata. Ciência Rural, v. 30, n. 3, p. 541-548, 2000.

PRATA, L. F. Avaliação da técnica de exame do coração na detecção de cisticercose suína, durante a inspeção em matadouros. Higiene alimentar, v. 1, n. 3-4, p. 205-213, 1982.

REIS, D. O. et al. Cisticercose bovina: 15 anos de ocorrência em animais abatidos em Uberlândia, Minas Gerais, Brasil. Higiene alimentar, v. 10, n. 43, p. 33-35, 1996.

SAKAI, H. et al. Seroprevalence of Taenia solium cysticercosis in pigs in Bahia State, Northeastern Brazil. American Journal Tropical Medicine and Hygiene, v. 64, n. 5-6, p. 268-269, 2001.

SCHENK, M. A. M.; SCHENK, J. A. P. Prevalência de tuberculose e cisticercose em bovinos abatidos nos matadouros-frigoríficos do Estado de Mato Grosso do Sul. Campo Grande: Comunicação Técnica Centro Nacional de Pesquisa de Gado de Corte, 1982.

SCIUTTO, E. et al. Taenia solium disease in humans and pigs: an ancient parasitosis disease rooted in developing countries and emerging as a major health problem of global dimensions. Microbes and Infection, v. 2, n. 15, p. 1875-1890, 2000.

SILVA, M. C. et al. Cisticercose suína, teníase e neurocisticercose humana no município de Barbalha, Ceará. Arquivos Brasileiros de Medicina Veterinária e Zootecnia, v. 59, n. 2, p. 371-375, 2007.

UNGAR, M. L.; GERMANO, P. M. L. Prevalência da cisticercose bovina no Estado de São Paulo (Brasil). Revista de Saúde pública, v. 26, n. 3 , p. $167-172,1992$. 